\title{
ARTICLES
}

\section{The Federation of Labour's right to bargain campaign: its background, impact and effectiveness}

\author{
Raymond Harbridge and Don Edwards*
}

In a period where trade union organisation was persistently attacked by the Government and denied the right to industrial bargaining, union leaders of the 1980s have committed themselves to a widespread understanding of industrial and wider economic issues facing working people. Organisationally the Federation of Labour (FoL) set out to achieve this through the development of the "campaign" strategy. The campaigns included meetings, rallies, and short industrial stoppages. The first of the campaigns took place in 1980 and the most recent in 1984. This research examines the 1984 FoL campaign - the right to bargain campaign - and reveals that it was one of New Zealand's largest ever single industrial disputes, with over 57000 workers losing over 125000 working days in less than 3 months. The extent of the campaign reflects the increased ability of the FoL to coordinate and direct a campaign in selected areas. The campaign came to an abrupt end when Prime Minister, Sir Robert Muldoon, called an unscheduled General Election. This led the FoL to direct its efforts away from industrial stoppages and towards the election of a Labour Government. Labour won the 1984 election, winning particularly well in the major city centres. The authors hypothesise that the educative impact of the right to bargain campaign was in part responsible for that electoral victory and to that extent the campaign could be considered a success.

\section{Introduction}

The last 5 years of Sir Robert Muldoon's National Government, the period from 1979 to 1984 , provided the trade union movement in New Zealand with one of its most testing periods ever. A succession of Government interventions in industrial relations, aimed at restricting trade union rights, were epitomised by 2 major policy enactments. In June 1982, the Prime Minister announced a wage and price freeze by regulations passed under the Economic Stabilisation Act (1948). The effect of this was to totally freeze all industrial negotiations over industrial matters unless approval was first given by Cabinet. This freeze lasted throughout 1983 and wage bargaining did not take place again until December 1984.

The second change to New Zealand's industrial relations system during this period was the introduction of the Industrial Law Reform Bill 1983. This had the effect of abolishing and completely prohibiting the post-entry closed shop system of union membership that New Zealand had operated under since the mid $1930 \mathrm{~s}^{1}$

The secretary of the Federation of Labour $(\mathrm{FoL})$ claimed that the introduction of

* Industrial Relations Centre, Victoria University of Wellington, New Zealand. The authors express their gratitude to: the Officers of the NZFoL for permission to quote from unpublished NZFoL material; Chris Eichaum, Craig Hill, Victoria Keesing, Linda Sissons, Pat Walsh and the journal's anonymous referees for their constructive comments on an earlier draft; Dave Atmore for his assistance with the computer analysis. The research was supported by research grant $157 / 84$ of Victoria University's Internal Research Committee.

1 For an analysis of the impact of this change see Harbridge and Walsh, 1985. 
the legislation to implement the abolition of the closed shop followed "a whole series of initiatives and actions taken by this (National) Government against the trade union movement or sections of the trade union movement." He cited 21 examples of legislative moves against the trade union movement and concluded "I say New Zealand unionism is under its greatest challenge for decades" (Douglas, 1983, p33).

This challenge led trade unionists to mount a series of campaigns as a response "to the persistence of high unemployment levels, the enforced reduction in real wages of workers and the legislative attacks" (Douglas, 1984, p. 115).

The development of the campaign strategy needs to be seen in the context of 2 significant new directions within the union movement. The first new direction was the closer liasion and co-ordination of activity between public and private sector unionists and the move to decentralise public sector union activity. The second new direction was the development of the grass-roots orientated "campaign" approach to the development of union organisation and support for union policies. This approach differed from that of the "Rob here, Tom" personal and top-level approach that Prime Minister, Sir Robert Muldoon, had had with the FoL's Sir Tom Skinner. ${ }^{2}$

Sir Tom Skinner retired from the Presidency of the FoL in 1979 and a new style of trade union leadership has emerged in New Zealand since then. That new style is committed to developing a widespread understanding of not just industrial issues but the wider social and economic decisions facing working people in New Zealand. The focus of this new approach has been the development by the FoL of an alternative economic strategy designed to promote debate about the social and economic decisions taken by Government. A former FoL economist has outlined this policy:

\begin{abstract}
Unions have increasingly realised that workers' living standards are determined not only by wages and conditions but also by the taxes that they pay, the benefits they receive from the Government expenditure, the inflation rates they face, their prospects of getting a job, and the overall direction (or lack of it) of economic development. Even if one limits the role of the unions to being only concerned about the living standards of union members, it would still be necessary for the union movement to develop a position on such issues (Kirk, 1983, p. 218).
\end{abstract}

Not only was the policy different, so was the method of obtaining support for that policy, achieved predominantly through the development of the union "campaign" among rank and file members and the general public.

\title{
Previous campaigns
}

The first of the campaigns, the defence of living standards campaign, began in 1980 . It was aimed to publicise the impact of Government expenditure cuts on working people, and the necessity for a wage increase to compensate for cost of living increases. The campaign centred around a "fortnight of action" launched in Auckland on 29 May 1980 at a meeting attended by more than 1000 union officials and delegates (Scott, 1980).

This campaign saw a marked increase in co-operation between private and public sector unionists and this closer liasion was noted in the FoL's annual report to the 1981 conference:

It needs to be recognised that the defence of living standards campaign could have only reached the measure of success that it did by the enthusiastic goodwill and co-operation of the affiliates and members of the Combined State Unions (CSU) (NZFoL, 1981, p. 8).

The 1982 annual conference of the FoL resolved to continue the "campaign"

2 "Rob here, Tom" is the title of a chapter in Sir Tom Skinner's autobiography in which Skinner outlines his relationship with Muldoon. See Skinner and Berry (1980). 
approach and decided to launch a 5-point campaign to publicise the harmful effects of a wage-tax trade off, to voice opposition to Government wage controls, and to stress the need for a minimum living wage, the right to a cost of living adjustment and the desirability of tax reforms (Roth, 1982a). In addition a significant development in union organisation was reported with the establishment of regional committees by the CSU as a follow on from the defence of living standards campaign (NZFoL, 1982).

The co-operation between the FoL and the CSU continued in this series of campaigns with the promotion in 1982 of a joint newspaper Campaign against the cuts in living standards and a FoL/CSU meeting on 1 September 1982 which approved a plan for protest action against the wage freeze. Stop work rallies, open to all members of the public, were to be held around New Zealand to demand an immediate wage increase, an adequate living wage and more jobs. These culminated in a special conference held in November 1982 (Roth, 1982b).

The 36 stop-work rallies that resulted were attended by over 90000 people, the smallest rally being at Taihape where 90 attended and the largest at Auckland where a massive lunch march up Queen Street was attended by a crowd estimated to be as large as 60000 (Roth, 1983a).

The rallies were seen by the FoL as:

\begin{abstract}
Extremely successful in agitating a wider public opinion and concern over the economic issues confronting the population of New Zealand. The rallies made a very solid foundation for the special conference of the FoL held on 18 November. The experience in all areas, of distributing the campaign newspapers, mobilising local support and co-ordinating activities on a national basis, was the most successful ever carried out by the FoL and the CSU (NZFoL, 1983, p. 27).
\end{abstract}

The FoL special conference on 18 November 1982 called for the Government and employers to award a $\$ 20$ a week wage increase as an interim compensation for cost of living increases occuring during the period of the wage freeze imposed on 22 June 1982. The 1983 FoL conference reaffirmed the demand for the $\$ 20$ a week interim increase and following the conference the campaign for the $\$ 20$ a week pay increase gathered momentum, particularly in Auckland. There on 3 June 1983 the Combined Union Information Service claimed that there was stop-work action taking place in more than 200 jobs. A spokesperson stated:

\begin{abstract}
We've had more people involved in industrial activity in the past 2 weeks than in the one day stoppage in 1979. It is probably the greatest industrial activity in New Zealand's history. Ninety-two industries, companies and jobs in Auckland have voted to take some form of industrial action such as brief stoppages, overtime and export bans and work to rules (Quoted in Roth, 1983b).
\end{abstract}

The campaigns so far had not achieved an across the board interim wage increase for all workers, nor had they achieved a return to bargaining rights for all unions. In recognition of this, in early July 1983, the Auckland Trades Council decided to highlight the right of unions to negotiate awards rather than the \$20 campaign. The CSU were late entering the campaign. In mid October they intensified the campaign against the wage freeze which the CSU had renamed the "great State pay robbery" when some 30000 state servants in Auckland took part in various protest activities including a 1-hour stoppage at Government offices (Roth, 1983c).

Despite the lack of success in gaining the " $\$ 20$ ", the FoL reviewed the campaign by stating:

The experience of this campaign indicated a significant increase in involvement of unions and workers in all regions of the country. The experience gained by the trade union movement during these campaigns will prove to be a decisive factor in the continuation of mobilisation of workers around the demands of the trade union movement as a consequence of the Industrial Law Reform Bill (NZFoL, 1984a). 
The right to bargain campaign: objectives

The right to bargain campaign was undertaken in the context of the persistent attacks by the Government on union organisation. The national council of the FoL resolved that the campaign was directed at:

... consolidating the activity of the trade union movement around the issues of trade union rights, wage levels, jobs and the election of a Labour Government. That the national council calls upon all district councils and affiliates to convene rank and file membership meetings, meetings of delegates and union representatives to hear reports directly from the representatives of the national executive for the purpose of:

- mobilising support around the policy of the CSU and Federation of Labour statement

- developing combined union action to implement this policy

- developing local activity in conjunction with other groups, particularly the unemployed and beneficiaries in mobilising support for opposition to the policies of this Government (NZFoL, 1984b).

The position adopted by the national council at its February meeting was confirmed by the national executive at a special meeting on 23 March 1984 . That meeting was called to examine a statement by the Prime Minister that there would be a general wage increase of $\$ 8$ only from 1 April 1984 and an indefinite extension of the wage freeze. The national executive resolved that:

This situation cannot be accepted. Accordingly, unions will be supported by the Federation of Labour in action taken to protect their members by achieving direct negotiations with their employers (NZFoL, 1984c).

Within a week the Prime Minister's statement about the general wage increase, the New Zealand Herald reported that "Industrial turbulence continued in parts of New Zealand yesterday as union protest grew against the $\$ 8$-a-week general wage order" 3 The report identified "turbulence" at a car assembly plant, a meat processing works, a fish processing factory, and a pulp and paper plant. In the 3 months that followed, a wide range of industries and employers became the target for industrial action. Two industries, however, the meat processing industry and the waterfront industry, were particularly prominent on a national basis.

In April 1984, the New Zealand Meatworker's Union approached the New Zealand Freezing Companies Association and asked them to make a joint approach to the Government to allow conciliation talks for a new national award to take into account changing conditions in the industry. The Freezing Companies Association refused to make such a joint approach to the Government with the result that the national executive of the New Zealand Meatworker's Union decided to start a rolling campaign, in line with the policy decision of the FoL's national council and designed to encourage freezing companies to change their stance. The rolling campaign commenced on 30 April 1984. The secretary of the New Zealand Meatworkers' Union outlined the form of the action as "The lucky marble to determine where the first rolling stoppage will occur will be drawn out of a hat at daybreak. There will be a phone call to the branch secretary concerned. He will communicate with the sub-branches, and the men will be told it's a homer" 4 In the 4 weeks that followed, all freezing works in New Zealand drew "the lucky marble" twice, some drew it 3 times. The New Zealand Waterside Workers' Union joined the meatworkers in their campaign of rolling stoppages against the wage freeze and in support of FoL policy, on 7 May 1984, the eve of the FoL's annual conference. Watersiders in all but 
2 of the 12 ports around New Zealand struck for a 24-hour period. As will be shown later, the combined actions of the New Zealand Meatworkers' Union and the New Zealand Waterside Workers' Union contributed 50 percent of the workers involved in the campaign, and were clearly a significant force in shaping the campaign. They were by no means, however, the only groups of workers involved in the campaign. The campaign of industrial action met with an abrupt and unscheduled end, when, on Thursday 14 June 1984, Sir Robert Muldoon announced that resulting from his inability to control his own caucus there would be a "snap" general election on 14 July 1984. The FoL and affiliated unions directed their attention away from industrial action, and towards that aspect of the right to bargain campaign designed to elect a Labour Government.

The actions of the meatworkers, watersiders, and other workers in the response to the FoL's call for action, are the subject of this research in an attempt to examine the impact of the right to bargain campaign on union effectiveness in New Zealand.

\section{Measuring the right to bargain campaign}

The FoL policy of having affiliated unions and district councils convene rank and file meetings for the purpose of hearing reports and of mobilising support and union action, was a key determinant in the success or otherwise of the campaign. Support for the campaign took several forms, generally focusing on the issues of bargaining rights over wage levels. Trade unionists made specific wage claims on their employers and, when that claim was rejected, took limited industrial action - generally in the form of a strike. Other forms of support included moral and financial assistance for workers involved in any extended stoppage - the moral support coming through the passing of resolutions of support at stop-work meetings and the financial support coming through donations of money and food. In attempting to evaluate the nature and extent of the campaign it was simply not possible to measure the number of rank and file meetings held, the number of supportive resolutions passed, nor the level of financial contributions made from unionists. In the case of some unions, the support offered to the campaign at this level was significant. For example, the Auckland branch of New Zealand's largest private sector union, the New Zealand Engineers Union, was 1 union not only heavily involved in the stoppages aspect of the campaign, but also in other aspects. The union branch aimed to avoid causing major inconvenience to the public and to engender rank and file support in shops with 30 or more financial members, requesting financial and moral support for all those taking action. Fifty seven percent (13 207 members) of the branch work in shops with 30 or more union members. On April 3, 1984, 133 engineers union members at the Auckland factory of Union Carbide, took indefinite stoppage action. In the weeks that followed the Union Carbide walkout, over 80 percent (10 743 members) of these larger workplaces were involved in campaign meetings, at 96 different job sites. In addition the union estimates a further 80 meetings were held in shops with fewer than 30 members. Union sources report that the majority of these meetings were site meetings of all unions, not only engineers. The union declined to reveal the level of financial support raised for the strikers but it is believed to be substantial. ${ }^{5}$

Likewise there is no direct way of measuring the extent to which employers conceded to union claims during this period. It would be reasonable to conclude that many employers agreed to union claims, ignored the Wage Freeze Regulations 1982, and didn't notify their assent to union claims to either the Arbitration Court or the news-media. This contention is supported by evidence that during the 1981-1982 wage round, for example, approximately two thirds of voluntary settlements negotiated by 1 major union were not registered with (or notified to) the Arbitration Court as was then required by the

5. The unions branch organisers were required to keep details of job sites visited, numbers attending, resolutions passed, money raised etc. This information was made available to the authors, on an aggregate basis, by the union. 
Wage Adjustment Regulations 1974 (Harbridge, 1983a).

In measuring the campaign, it is necessary to identify easily accessible and tangible features of the campaign and for this reason, this research concentrates on industrial stoppages - where production time was lost - be they extended stopwork meetings, one-day stoppages, protracted strikes, or load-out bans. Evidence of this industrial campaign was initially sought by examining newspaper reports of the campaign. Harbridge (1984b) has shown that disputes feature prominently in industrial reporting and that local industrial disputes and issues are frequently reported in the local papers. Consequently, 10 of New Zealand's 30 daily newspapers were examined for the period from 23 March 1984 to 30 June 1984. The papers examined were the Northern Advocate in Whangarei, the New Zealand Herald in Auckland, the Waikato Times in Hamilton, the Hawkes Bay Herald in Napier, the Manawatu Evening Standard in Palmerston North, The Dominion, and The Evening Post in Wellington, the Press in Christchurch; the Otago Daily Times in Dunedin, and the Southland Times in Invercargill.

The information provided in the newspaper items was checked with the employer and union cited. Industrial relations and personnel officers, along with trade unionists, were helpful and forthright in providing the data sought. In addition many employers and unions contacted were able to identify other disputes that had not received newspaper coverage. Other disputes were identified by direct contact with officials of the FoL and the New Zealand Employers Federation. These additional disputes were checked and are included in these results.

The information sought about the industrial action included the total number of workers employed by the employer; whether the dispute involved more than one union; type of industrial action taken; length of that action and whether there was any follow-up action taken; number of workers involved in the action directly (through strike action) and indirectly (through employer initiated suspensions of workers under Part IX of the Industrial Relations Act 1973); the number of working days lost directly or indirectly; the industrial district; and the employers industrial sector.

Each dispute observed has been recorded as a separate dispute. For example, each meat processing works that lost production as a result of a strike by members of the New Zealand Meatworkers' Union was recorded separately although this series of rolling stoppages was the result of 1 dispute between the union and the New Zealand Freezing Companies Association. Where a second strike or other action followed, that action was not recorded as a new dispute but as a continuation of the first dispute.

\section{The extent of the right to bargain campaign}

The campaign of industrial action lasted 87 days. The first dispute began on 26 March 1984 and the final dispute ended on 20 June 1984 - less than 1 week after the announcement of the snap general election. In that period 152 work stoppages were identified. Of these 56 involved the New Zealand Meatworkers' Union, 12 involved the New Zealand Waterside Workers' Union, and the remaining 84 were spread over a wide range of industries.

Throughout New Zealand, a total of 57264 workers took direct action supporting the campaign. Forty five percent of these (25 893) were members of the New Zealand Meatworkers' Union and a further 5 percent $(2$ 771) were from the New Zealand Waterside Workers' Union. A total of 126793 working days were lost, 48 percent (61 413) by meatworkers and a further 2 percent $(2771)$ by watersiders. The total number of workers involved and the total number of working days lost represent approximately one third of working days lost in all industrial stoppages in New Zealand in any of the last 6 years. These comparative figures are presented in Table 1. In addition they show that the average duration of each stoppage was less than 3 days and that the average number of days lost per worker involved was 2.21 days. 
Table 1: Right to bargain campaign : workers involved and working days lost compared with all stoppages $1978-83$

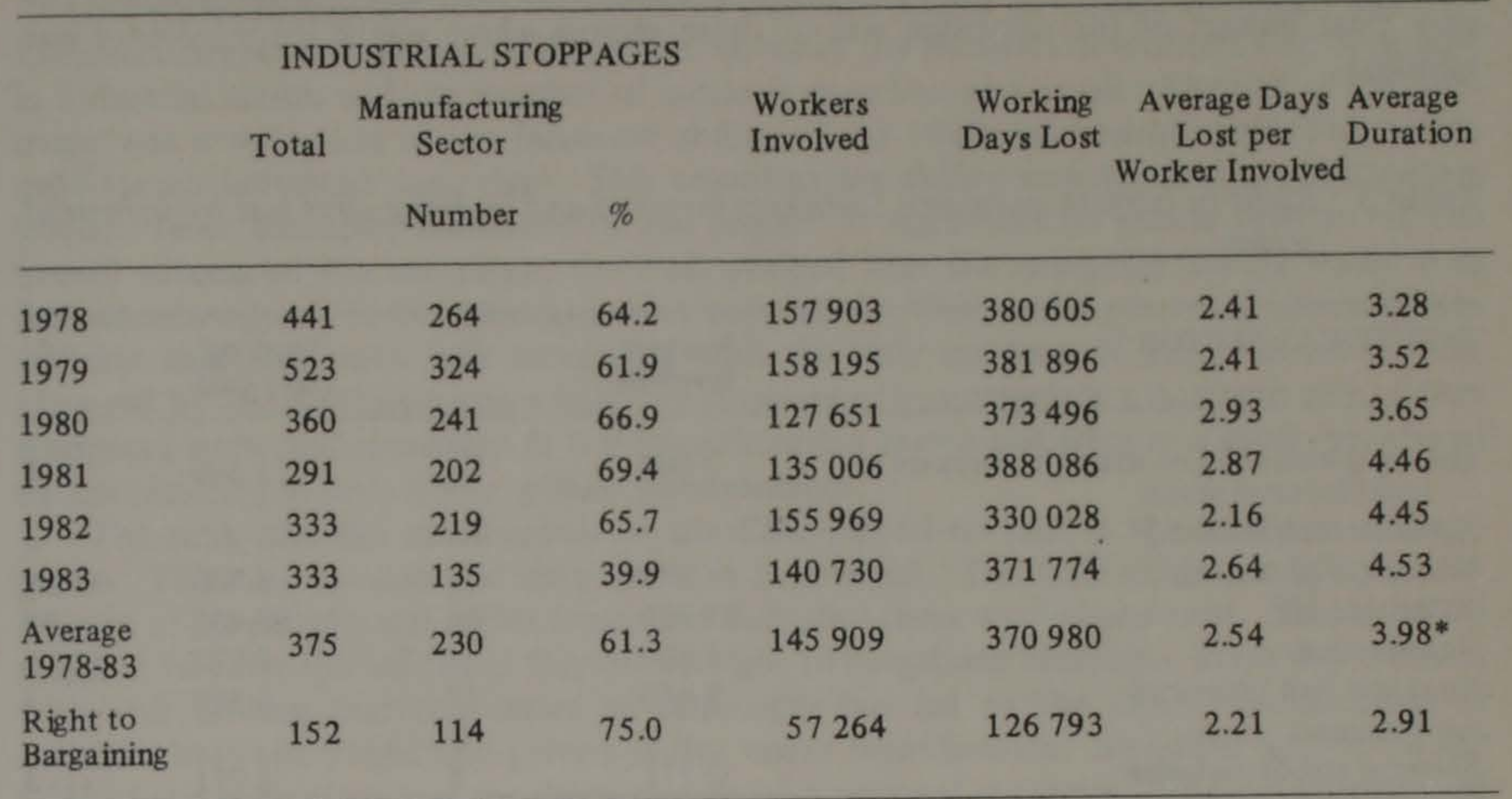

* Average of averages

Table 2 presents the figures for workers involved in the campaign and working days lost by industrial district. Forty seven percent $(27037)$ of the workers involved were in the Northern industrial district (Nid) losing 43 percent (54 972) of the working days lost. This pattern is consistent with normal patterns of industrial stoppages in New Zealand. The heavily populated manufacturing oriented Nid accounted for 46 percent of working days lost in all stoppages over the period from 1978 to $1982 .^{6}$ Support for the campaign predominated in the Nid. When the industrial action of workers other than meatworkers and watersiders is considered, the importance of workers domiciled in the Nid is recognised. They represented 72 percent $(20657)$ of the "other" workers involved and lost 68 percent $(42818)$ working days in the campaign. Clearly the impact of the workers in the Nid was critical to the campaign's potential success, and far outstripped ordinary stoppage rates in the Nid.

Table 2: Right to bargain campaign : workers involved and working days lost by industrial district

\begin{tabular}{|c|c|c|c|c|c|c|c|c|c|c|}
\hline \multicolumn{11}{|c|}{ INDUSTRIAL DISTRICT } \\
\hline & & North. & Taranaki & Wgtn & Nelson & Cant. & Otago & South. & Total & $\%$ \\
\hline \multirow{5}{*}{$\begin{array}{l}\text { Workers } \\
\text { Involved }\end{array}$} & Freezing Workers & 5476 & 1921 & 6773 & 465 & 4160 & 1618 & 5480 & 25893 & 45 \\
\hline & Watersiders & 904 & - & 717 & 108 & 630 & 172 & 240 & 2771 & 5 \\
\hline & Others & 20657 & 1740 & 2098 & 900 & 1402 & 1803 & - & 28600 & 50 \\
\hline & Total & 27037 & 3661 & 9588 & 1473 & 6192 & 3593 & 5720 & 57264 & 100 \\
\hline & $\%$ & 47 & 6 & & & & & & 100 & \\
\hline \multirow{5}{*}{$\begin{array}{c}\text { Working } \\
\text { Days } \\
\text { Lost }\end{array}$} & Freezing Workers & 11250 & 3770 & 16191 & 903 & 8306 & 4849 & 16144 & 61413 & 48 \\
\hline & Watersiders & 904 & - & 717 & 108 & 630 & 172 & 240 & 2771 & 2 \\
\hline & Others & 42818 & 7285 & 7609 & 2150 & 1838 & 909 & - & 62609 & 50 \\
\hline & Total & 54972 & 11055 & 24517 & 3161 & 10774 & 5930 & 16384 & 126793 & 100 \\
\hline & $\%$ & 43 & 9 & 19 & 3 & 8 & 5 & 13 & 100 & \\
\hline
\end{tabular}

6. Source: Department of Statistics 
The right to bargain campaign was concentrated in the manufacturing sector with 66 percent (37 805) of the workers involved and 78 percent $(99400)$ of the working days lost. Table 3 reports workers involved and working days lost by industrial sector. The very clear impact of the campaign was in those sectors where public inconvenience was minimal.

Table 3 : Right to bargain campaign : workers involved and working days lost by industrial sector

\begin{tabular}{lcccr}
\hline INDUSTRIAL SECTOR & $\begin{array}{c}\text { Workers } \\
\text { Involved }\end{array}$ & $\%$ & $\begin{array}{c}\text { Working } \\
\text { Days Lost }\end{array}$ & $\%$ \\
\hline $\begin{array}{l}\text { Mass stopworks and/or st rikes by workers in } \\
\text { multi-industry group }\end{array}$ & 3000 & 5 & 1500 & 1 \\
$\begin{array}{l}\text { Agriculture and Grazing } \\
\text { Mining and Quarrying }\end{array}$ & - & - & - & - \\
Manufacturing & 37805 & -66 & 6300 & 5 \\
Construction & 1500 & 3 & 69700 & 78 \\
Road and Rail Transport & 9440 & 17 & 6360 & 5 \\
Air Transport & - & - & - & - \\
Shipping and Stevedoring & 2771 & 5 & 2771 & 3 \\
Finance Insurance Real Estate & 98 & - & 1016 & 1 \\
Wholesale and Retail Trade & 1980 & 3 & 2571 & 2 \\
Government and Local Authority & - & - & - & - \\
Recreational Services & - & - & - & - \\
Social Community Services & - & - & - & - \\
Other Personal and Community Services & - & - & - & - \\
TOTAL & 57264 & 100 & 126793 & 100 \\
\hline
\end{tabular}

Only 24 of the disputes ( 15 percent) were multi-union disputes involving more than 1 union. The most common form of industrial action taken was strike action, being reported in 127 cases ( 83 percent). Extended large stopwork meetings were recorded in 15 cases (10 percent). Other forms of action included the imposing of loadout and overtime bans. Most industrial action was a oneoff action with followup industrial action being recorded in 54 cases ( 34 percent). The followup action was invariably strike action and in 21 cases (14 percent) 3 or more separate stoppages followed the original stoppage.

The industrial action was most likely to occur at workplaces of large companies. Fifty seven percent of disputes occured at companies employing more than 1000 workers and only 10 percent occured at companies employing less than 50 workers. Stoppages, then, occured at unusually large workplaces by New Zealand standards. New Zealand employers are not required to make any official returns of their total number of employees. However, in the manufacturing sector - the sector in which over 75 percent of the right to bargain disputes occured -51 percent of establishments (as opposed to companies) employ less than 10 workers, and only 0.02 percent of establishments employ more than 1000 workers $^{7}$ Notwithstanding this trend for workers in large rather than small companies to stopwork over the campaign, the stoppages have been limited to comparatively small areas within individual companies and the total workforce of a company has been rarely involved in a stoppage. Seventy one disputes (47 percent) involved 100 or less workers and only 13 disputes (10 percent) involved more than 1000 workers at the same time.

Employers were clearly reluctant to invoke the suspension of non-striking worker provisions available to them under part IX of the Industrial Relations Act 1973. Only 9 instances of employer initiated suspensions were recorded. There were 1698 workers suspended, who lost 7906 working days as a result. No doubt this employer reluctance was in part due to the fact that each industrial stoppages was of a short duration.

7. New Zealand Official Yearbook 1983, Wellington, Government Printer, p. 503. 


\section{Discussion}

Notwithstanding the 1951 waterfront lockout, the right to bargain campaign was New Zealand's largest ever industrial dispute in terms of the numbers of workers who took part in industrial action and the number of working days lost as a result. The size of the campaign was a reflection of the increased ability of the 1980s leadership of the FoL to coordinate an industrial campaign. This co-ordinating ability was demonstrated at various levels. For example, conscious of the impact of unfavourable public opinion on the overall success of the campaign, the FoL decided that the campaign should result in as little inconvenience to the general public as possible. The results presented above clearly indicate that this tactic was successful, with the only incident of public inconvenience observed by the authors being a half day stoppage of bus drivers in a northern city. Other stoppages were predominately in the manufacturing sector and were of a short (yet sharp) nature resulting in little if any, public inconvenience.

The rank and file membership of the CSU played no part in the campaign of stoppages. This was because the snap election intervened. The CSU executive had planned a series of stopworks and rallies from early July, but these were abandoned. That the CSU was late to enter the industrial fray on the right to bargaining campaign, in no way detracts from our finding that this series of campaigns has led to the closer co-ordination of activities between public and private sector union organisations. An added benefit for the CSU of the campaigns was the development of a regional structure. The development of this joint FoL/CSU approach to campaign organisation has foreshadowed the proposal within the New Zealand trade union movement to have just 1 central organisation of workers, the New Zealand Council of Trade Unions. This proposal is designed to replace the present (increasingly artificial) distinction between private and public sector union organisations.

One of the more important outcomes from the development of the campaigns and their success, has been the ability of the trade union movement to start to change the nature of the industrial relations agenda in the eyes of the Government. This change replaces a narrow approach to "industrial relations" where only direct employer-worker matters are considered relevant to an agenda, to one in which the trade union movement is recognised as having a role in a tripartite setting, examining the nature and direction of New Zealand society and its economy. This changing of the agenda has been achieved through altering the expectations within the union movement. The educational impact of the campaigns has led to significant rank and file discussion and debate of issues related to the economy and its effect on working people. The rallies and meetings have had a considerable impact within the union movement in raising the consciousness of those attending, and altering the level of debate about those issues that are validly the concern of the trade union movement.

The organisational impact of the campaign in preserving the trade union movement in the face of voluntary unionism has been of concern to the FoL. At this stage it is too early to comment on the full impact of voluntary unionism on New Zealand unions, but the preliminary findings of Harbridge and Walsh (1985) indicated that with the exceptions of 2 union groups, membership losses were of the range of 1 to 5 percent. This finding, that the post-entry closed shop would be retained by the vast majority of those already belonging to unions, may be further evidence of the effectiveness of the campaigns. Those unions that played an important role in the right to bargain campaign were largely immune from the impact of voluntary unionism.

One of the objectives of the right to bargain campaign was the election of a Labour Government in the scheduled November 1984 election. While the calling of the snap election altered the timing of the election by 4 months, it intensified union efforts to ensure a Labour victory. When the snap election was announced the attention of the union movement was directed from industrial action to electoral support for Labour. The form of the activity changed but the aim of the activity was consistent. Labour won the election with a handsome (if not landslide) victory. 


\section{Harbridge and Edwards}

While it is acknowledged that there are many factors involved in every general election victory (and defeat), it is argued that the right to bargain campaign with its organisational and educational impact, was a very important factor in Labour's win. It is worth noting that following the July 1984 election, the National Party held only 6 seats from the main city centres in Parliament, and that as a political party National must now be seen as having representatives from only its rural rump. In the cities, where most of the rallies had taken place, Labour gained many National seats. In Wellington, for example, the National Party now holds no seats at all, and seats that 6 years ago were marginal National/Labour can now be considered safe Labour seats.

The Dominion, in reviewing the events of 1984 , headlined one article "Strikes, more strikes and victory for Lange". The strikes referred to in the headline include stoppages over voluntary unionism and site disputes at the Marsden Point refinery expansion site. The right to bargain campaign is dismissed as:

The freezing workers began random stoppages - later joined by waterside workers - in
what turns out to be a futile bid to force a return to free wage bargaining.

Of real interest here, however, is that the general tenor of The Dominion article was that the strikes and the election of Lange's Labour Government were discrete, independent events. In fact, the weight of evidence is that the right to bargain and its predecessor campaigns led indirectly (if not directly) to Lange's election.

That The Dominion failed to examine the link between the strikes, the campaigns and Labour's election success, is hardly surprising. The approach of the newspapers throughout the right to bargain campaign was to faithfully report disputes and incidents as they occurred, but to fail to analyse the overall significance and impact of the campaign. The authors saw no newspaper attempt an analysis of even the size of the campaign let alone its political significance.

\section{Conclusion}

The right to bargain campaign was no doubt dismissed by many as a futile, non-event. The research reported here however, questions such a conclusion. The campaign was definitely a major event on the New Zealand industrial scene, being one of the largest single issue industrial stoppages since the 1951 waterfront lockout. As an organisational exercise, the campaign has led to far greater involvement by rank and file trade unionists in considering the wider economic issues facing New Zealand and working people. In addition, the closer relationship between the FoL and the CSU has meant that the union movement in New Zealand has come much closer to speaking with 1 voice when dealing with Government. This closer relationship between private and public sector unionists at peak council level has had a downstream effect with CSU representatives now attending FoL district Trades Council meetings, helping to decentralise the CSU. These organisational developments reflect a major shift in union leadership and direction since the retirement of Sir Tom Skinner. The educational impact of the campaign can be seen in the result of the General Election. One of the objectives of the campaign was the election of a Labour Government, which for the FoL was possibly the only way left to end the National Government's wagefreeze. The impact of limited or sustained industrial action was designed to encourage employers to approach Goverment to change the rules and life the freeze. The Government, however, continued to make it clear that it would not bow to such pressure and the only way open to lifting the wage-freeze became to change the Government. The election of a Labour Government led, within 5 months, to the restoration to unions of the right to bargain - albeit constrained bargaining. The challenge to the Labour Government in its term will be to respond to the trade union movement with economic policies that will 
capitalise on the support that has developed for alternative economic policies by the FoL/ CSU campaigns. If the Labour Government fails to win the support of the trade union movement for its economic policies, it will be interested to see whether Labour can remain in Government after the next election given the substantial organisational and educational support it received in the last.

\section{References}

Douglas K G (1983) Implications of Voluntary Unionism : the union perspective. In Brosnan P (ed.) Voluntary Unionism Industrial Relations Centre, Victoria University of Wellington, 31-36.

Douglas K G (1984) Campaign for the return to free wage bargaining. New Zealand journal of industrial relations 9 (2) : 113-116.

Harbridge Raymond (1983a) The treatment of industrial relations in three major New Zealand newspapers. New Zealand journal of industrial relations 8 (1) : 11-21.

Harbridge Raymond (1983b) A comment on the extent of voluntary bargaining in New Zealand industrial relations. New Zealand journal of industrial relations 8 (3) : 193 196.

Harbridge Raymond and Walsh Pat (1985) Legislative prohibiting and closed-shop in New Zealand: its introduction and consequences The journal of industrial relations 27 (2): 191-206.

Kirk Alf (1984) The trade union response to structural change New Zealand journal of industrial relations 8 (3) : 211-221.

New Zealand Federation of Labour (1984) 44th annual report Wellington, FoL.

New Zealand Federation of Labour (1982) Minutes and report of the proceedings of the 45th annual conference held in the Town Hall, Wellington, on May 4, 5, 6 and 7, 1982. Wellington, FoL.

New Zealand Federation of Labour (1983) Minutes and report of the proceedings of the 46th annual conference held in the Town Hall, Wellington, on May 3, 4, 5, and 6, 1983. Wellington, FoL.

New Zealand Federation of Labour (1984a) 47th annual report Wellington, FoL.

New Zealand Federation of Labour (1984b) Minutes of national council held at the Federation of Labour building, Lukes Lane, Wellington, on Wednesday 29 February, 1984 Wellington, FoL.

New Zealand Federation of Labour (1984c) Minutes of special meeting of National Executive held at the Federation of Labour building, Lukes Lane, Wellington, on Friday 23 March, 1984 at 9.30am Wellington, FoL.

Roth H (1982a) Chronicle New Zealand journal of industrial relations 7 (1) : 89-98.

Roth H (1982b) Chronicle New Zealand journal of industrial relations 7 (2) : 205-212.

Roth H (1983a) Chronicle New Zealand journal of industrial relations 8 (1) : 73-80.

Roth H (1983b) Chronicle New Zealand journal of industrial relations 8 (2) : 161-169.

Roth H (1983c) Chronicle New Zealand journal of industrial relations 8 (3) : 245-255.

Scott J (1980) Chronicle New Zealand journal of industrial relations 5 (2 and 3) : 50-58.

Skinner T and Berry J (1980) Man to man Christchurch, Whitcoulls. 